\title{
14-vs. 42-Paddock Rotational Grazing: Forage Quality
}

\author{
R.K. HEITSCHMIDT, S.L. DOWHOWER, AND J.W. WALKER
}

\section{Abstract}

Research was initiated at the Texas Experimental Ranch in 1981 to quantify the effects of 2 livestock densities on forage quality in a rotational grazing (RG) treatment. Livestock densities evaluated were equivalent to 14 and 42-paddock RG treatments. Baseline data were collected in 1981 from 3 adjacent 30-ha paddocks in a 465-ha, 14-paddock, cell designed RG treatment stocked at a rate of $3.6 \mathrm{ha} / \mathrm{cow} / \mathrm{year}$. Near the beginning of the 1982 growing season the center paddock was subdivided into three, 10-ha paddocks to establish the RG-42 treatment. Herbage standing crop was harvested before and after each grazing event during the 40 -month period, separated by species or species group into live and dead tissue, and each fraction analyzed for percentage crude protein (CP) and organic matter digestibility (OMD). Livestock density had minimial effect on forage quality. Live tissue was of higher quality than senesced tissue regardless of plant species. Increases and decreases in overall quality during graxing periods were positively associated with rates of plant growth. Number of periods when forage quality increased or decreased during graxing and magnitude of change were unaffected by treatment. Lack of significant treatment effects on forage quality is attributed to the general absence of significant treatment efiects on forage production, species composition, and live/dead ratios.

Key Words: rotational grazing, cell grazing, crude protein, organic matter digestibility

Interest in rotational grazing systems ( $R G$ ) has increased dramatically in the U.S. during the past 10 years. Of particular interest has been the claim that proper implementation of a multi-paddock RG system will improve livestock carrying capacity of rangeland (Savory and Parsons 1980). Although this claimed increase in carrying capacity has been attributed generally to increases in forage production, it also has been hypothesized that a portion of this increase can be attributed to an increase in forage quality (Gammon and Roberts 1978, Heitschmidt et al. 1982, Jung et al. 1985).

In 1981 we designed a series of studies to evaluate the effects of a RG treatment on quantity and quality of herbage produced and consumed, harvest efficiency, animal behavior, watershed condition, cow/calf performance, and economic profits. This paper is the fourth of a series that report on the effects of 2 livestock densities in a RG treatment on quantity of forage produced and consumed (Heitschmidt et al. 1987), watershed condition (Pluhar et al. 1987), and animal behavior (Walker and Heitschmidt 1986). In this paper we report the effects of a 3-fold increase in livestock density on forage quality in the RG treatment. Subsequent papers will contrast the response of the various parameters in the $R G$ treatment to those in a yearlong continuously grazed treatment.

\section{Methods}

The study was conducted at the 2,900-ha Texas Experimental Ranch located $\left(99^{\circ} 14^{\prime}, 33^{\circ} 20 \mathrm{~N}\right)$ on the eastern edge of the Rolling Plains resource region. The 465-ha, cell-designed (paddocks

\footnotetext{
Authors are associate professor, research associate and former research associate, Texas Agr. Exp. Sta., Box 1658, Vernon 76384.

Appreciation is expressed to the Swen b. Swenson Cattle Co. for providing the land livestock, and facilities for this study; the Texas Experimental Ranch Committee for providing financial assistance; to Dr. Trey Richardson, Institute of Statistics, Texas A\&M University, College Station, for assistance in data summarization and statistical analysis; and to Dr. M.M. Kothmann, Department of Range science, Texas A\&M University, for qualitative laboratory analyses

Report is published with approval of the Director, Texas Agr. Exp. Sta. as TA 21710.

Manuscript accepted on 17 February 1987.
}

radiating from a common center) $R G$ treatment was initiated in March 1981. Rate of stocking was $3.6 \mathrm{ha} / \mathrm{cow} /$ year from March 1981 until June 1984, after which rate of stocking was reduced to $5.1 / \mathrm{ha} / \mathrm{cow} /$ year because of drought (Heitschmidt et al. 1987).

Initially the treatment consisted of 14 paddocks that averaged 33 ha. In March 1982, one 30-ha paddock was subdivided into three, 10-ha paddocks, thereby creating a livestock density equivalent to that in a 42-paddock system. The 10-ha paddocks are hereafter referred to as the $\mathrm{RG}-42$ treatment and the 27 -ha paddocks as the RG-14 treatment.

Immediately before and after every grazing event from March 1981 to December 1984 , the herbaceous vegetation in ten, $0.25-\mathrm{m}^{2}$ quadrats was harvested at ground level by species/species group. Dominant species/species groups (hereafter referred to as species) and their designated codes were sideoats grama [Bouteloua curtipendula (Michx.) Torr.] (Bocu); Texas wintergrass [Stipa leucotricha Trin. and Rupr.] (Stle); annual grasses (Angr); other warmseason grasses (Wsgr); annual broomweeds [Xanthocephalum spp.] (Xasp); and other forbs (Forb). Following drying $\left(60^{\circ} \mathrm{C}\right.$ ) and weighing, estimates of live/dead ratios were made by weighing hand-separated subsamples of each species from each treatment. Live tissue was any tissue possessing green color. Before and after grazing subsamples were then combined across treatments by category (live and dead) and species for qualitative laboratory analyses. Percentage crude protein (CP) was estimated following standard A.O.A.C. (1970) procedures. In vitro organic matter digestibility (OMD) was estimated according to Tilley and Terry (1963) as modified by Van Soest and Wine (1967).

Live and dead CP and OMD standing crops ( $\mathrm{kg} / \mathrm{ha}$ ) were calculated for each species on all sample dates by multiplying live and dead organic matter standing crop estimates (Heitschmidt et al. 1987) by their respective \%CP and \%OMD values as determined in the laboratory. Live and dead CP and OMD standing crop estimates were summed and divided by total organic matter for overall \%CP and \%OMD. For example, assume for a given sample \%CP and organic matter standing crops were $10 \%$ and $50 \mathrm{~kg} / \mathrm{ha}$ for live Bocu and $5 \%$ and $70 \mathrm{~kg} /$ ha for dead Bocu. Average \%CP for Bocu was, therefore, $7.08 \%=[(.10 \times 50)+(.05 \times 70)] / 120$. Average \%CP and \%OMD for total standing crop was estimated by summing $\mathrm{CP}$ and OMD standing crop for each species and dividing by total organic matter standing crop.

All data were subjected to least squares analyses of variance utilizing a split block model (Little and Hills 1978) to test for the main effect of treatment (RG-14 vs. RG-42) and the subplot effect of time (before and after grazing). The error term for testing significant treatment effects $(P<0.05)$ was pastures within treatment. The residual was used to test for significant $(P<0.05)$ time and treatment by time interaction effects. Student $Q$ procedures (Snedecor and Cochran 1967) were used for mean separations where appropriate.

For a complete description of the study area see Heitschmidt et al. (1985). For a thorough description of the study design and field sampling procedures see Heitschmidt et al. (1987).

\section{Results and Discussion}

A major factor affecting forage quality of an individual plant is the physiological age of plant tissue (Cogswell and Kamstra 1976, Beaty and Engle 1980, Huston et al. 1981, Heitschmidt et al. 1982). Results from this study clearly indicated that live tissue was generally higher in percentage $C P$ and $O M D$ than dead senesced tissue (Figs. 1 and 2). Generally, quality of live tissue was more variable 

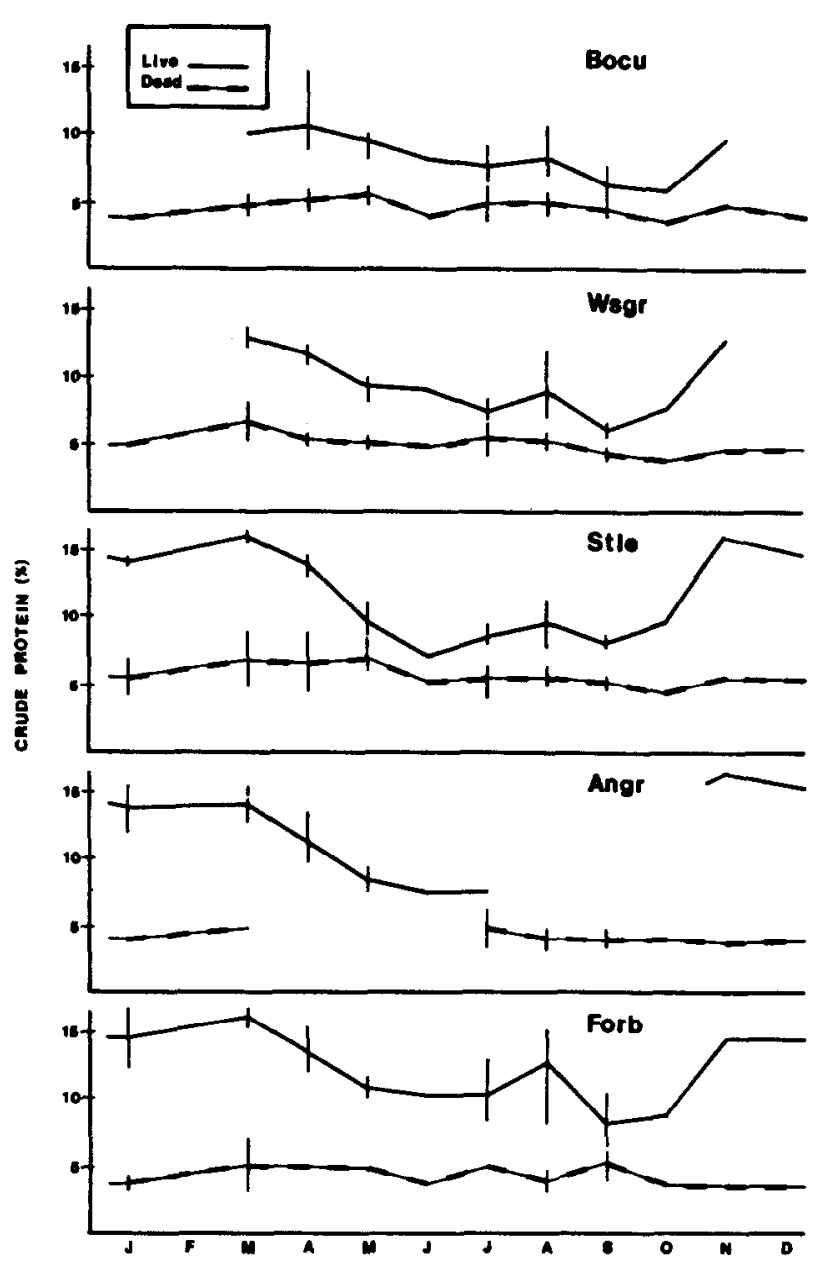

Fig. 1. Mean monthly crude protein concentrations (\%) for live and dead tissue of 5 species/species groups over a 40-month period. Vertical lines represent range of values. See text for identification code for species/species group.

among sample dates than quality of dead tissue, because quality of live tissue is relatively more sensitive to physiological age than dead tissue (Uresk and Sims 1975). Rate of tissue maturation is highly dependent on environmental growing conditions, and in a highly variable environment, quality of forage during a growing season or year can vary widely. Quality of live tissue over years generally followed the quantitative pattern of plant growth (Heitschmidt et al. 1987), increasing during periods of rapid growth and decreasing during periods of slow or no growth. The range in values was generally greatest in late summer because growing conditions during this period were variable and closely coupled to infrequent precipitation events.

Generally, percentage $\mathrm{CP}$ of the live tissue of the cool-season grass species (Stle and Angr) was greater than that of the warmseason species (Bocu and Wsgr) (Fig. 1). Maximums were about $16.5 \% \mathrm{CP}$ for Stle and $13.5 \%$ for Wsgr. Minimums were about 7.5\% for Stle and Angr and 5.0\% for Bocu. Percentage OMD of live tissue (Fig. 2) was generally less variable among species and sample dates than was \%CP.

Overall quality of available forage in this study was highly variable and reflected strong seasonal patterns (Fig. 3). The seasonal patterns were related closely to growth patterns as reported previously (Heitschmidt et al. 1987). Statistical analyses, however, indicated minimal treatment effects. Over the 25 sample dates, \%CP varied significantly between treatments only in April 1982, when $C P$ in the RG-14 treatment averaged $9.7 \%$ as compared to $8.9 \%$ in the $R G-42$ treatment. OMD varied significantly between
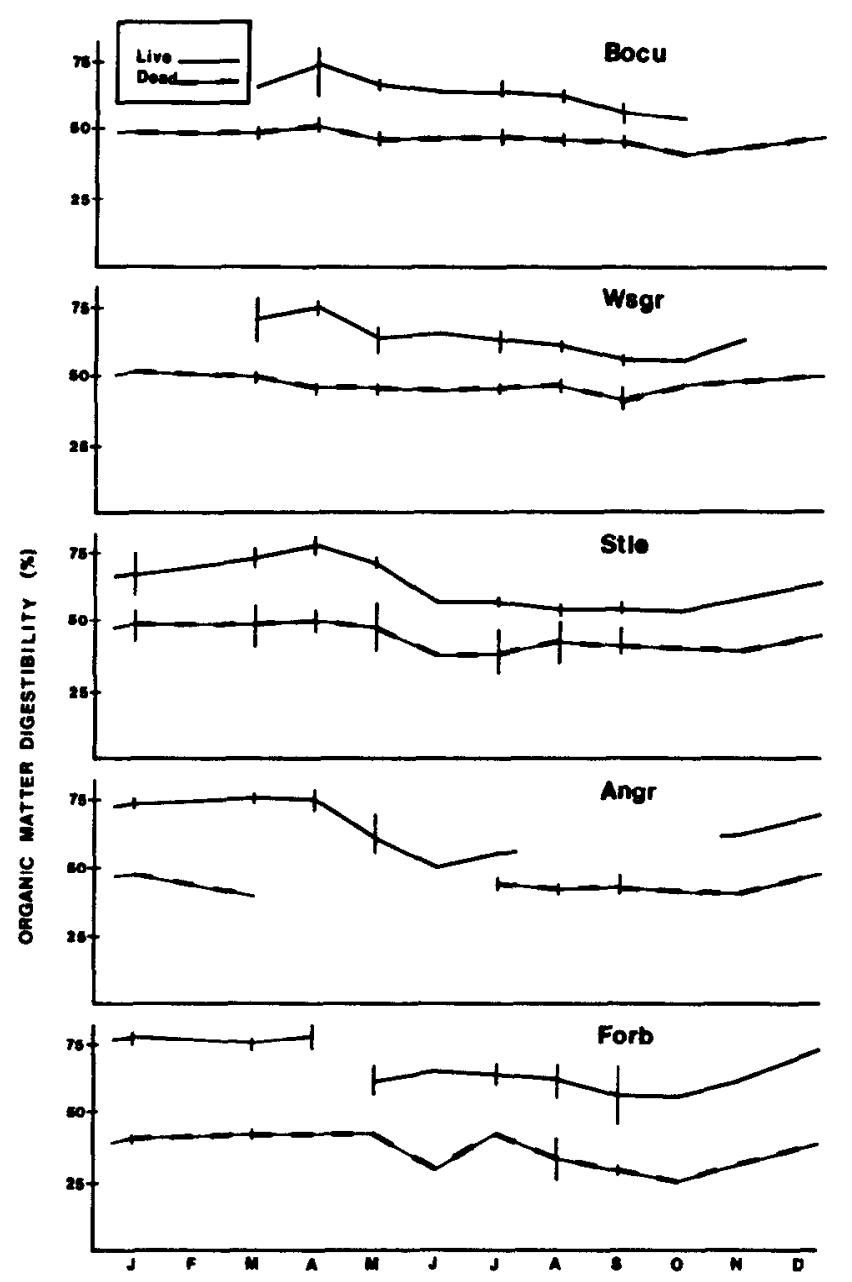

Fig. 2. Mean monthly organic digestibility (\%) for live and dead tissue of 5 species/species groups over a 40-month period. Vertical lines represent range of values. See text for identification code for species/species group.

treatments on 3 dates: August 1982, September 1982, and April 1983. On these 3 dates, OMD in the RG-14 treatment averaged $54.9,52.0$, and $64.1 \%$, respectively, as compared to $56.7,52.5$, and $61.1 \%$, respectively, in the $\mathrm{RG}-42$ treatment.

There were 9 instances when $\% \mathrm{CP}$ changed significantly during a grazing event and 7 instances when OMD changed significantly (Fig. 3). Declines in quality were generally asociated with periods of slow or no growth (Heitschmidt et al. 1987) while increses were generally associated with periods of rapid growth. Presumably, the declines reflected the effects of diet selection on overall forage quality. However, during periods of rapid vegetation growth, the negative effect of diet selection on overall forage quality was apparently less than the positive effect of new growth.

There were only three instances when the treatment by time interaction effect was significant for \%CP: June 1981, June 1983, and July 1983. However, absolute differences were small and not biologically interpretable. There were only 2 instances when the treatment by time interaction effect was significant for \%OMD: October 1982 and June 1983. These interactions were also considered to be of little biological importance.

\section{Conclusion}

Increasing number of paddocks in the RG treatment from 14 to 42 did not consistently alter forage quality over the year or during a grazing period. These results agree with concurrent studies which showed that neither forage production, plant species composition, 

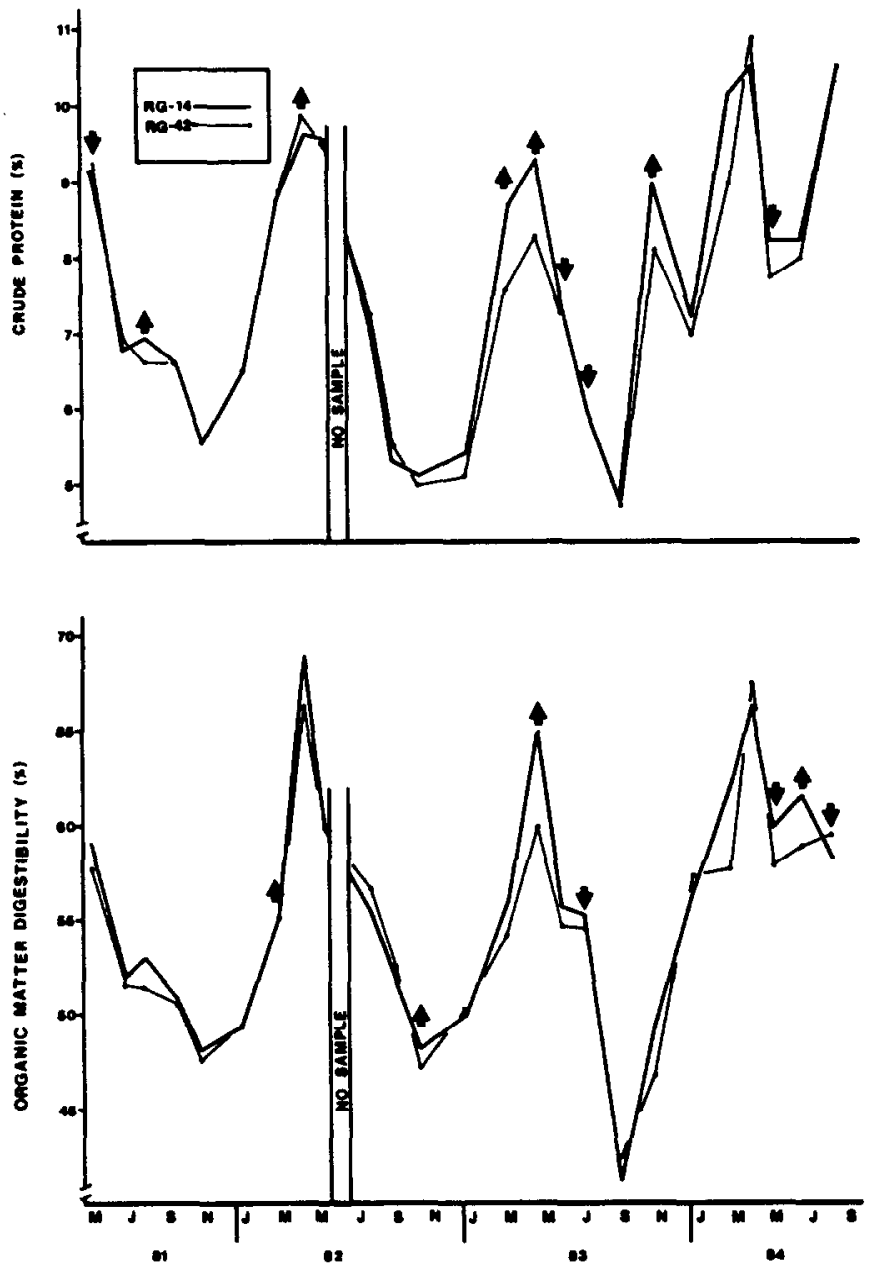

Fig. 3. Crude protein concentration (\%) and organic matter digestibility (\%) of total herbage standing crop in 14 (RG-14) and $42(R G-42)$ paddock rotational grazing treatments on 25 sample dates over a 40-month period. Data points are average forage quality values before and after grazing. Arrows ( $|\downarrow|$ ) represent sample dates when forage quality values either increased or decreased a significant $(\mathrm{P}<0.05)$ amount in one (4 dates) or both (12 dates) treatments. nor live/dead ratios were significantly altered when number of paddocks was increased from 14 to 42 (Heitschmidt et al. 1987).

\section{Literature Cited}

A.0.A.C. 1970. Official methods of analysis (1 lth ed.). Ass. Off. Agr. Chem., Washington D.C. 1015 p.

Beaty, E.R., and J.L. Engel. 1980. Forage quality measurements and forage research-A review, critique and interpretation. J. Range Manage. 33:49-54.

Cogswell, C., and L.D. Kamstra. 1976. The stage of maturity and its effect upon the chemical composition of four native range species. J. Range Manage. 29:460-463.

Gammon, D.M., and B.R. Roberts. 1978. Characteristics of herbage on offer during continuous and rotational grazing of the Matopos sandveld of Rhodesia. Rhod. J. Agr. Res. 16:3-22.

Heitschmidt, R.K., S.L. Dowhower, R.A. Gordon, and D.L. Price. 1985. Response of vegetation to livestock grazing at the Texas Experimental Ranch. Texas Agr. Exp. Sta. Bull. 1515.

Heitschmit, R.K., S.L. Dowhower, and J.W. Walker. 1987. 14- vs. 42paddock rotational grazing: aboveground biomass dynamics, forage production, and harvest efficiency. J. Range Manage. 40:216-223.

Heitschmidt, R.K., R.A. Gordon, and J.S. Bluntzer. 1982. Short duration grazing at the Texas Experimental Ranch: Effects on forage quality. J. Range Manage. 35:372-374.

Huston, J.E., B.S. Rector, L.B. Merrill, and B.S. Engdahl. 1981. Nutritional value of range plants in the Edwards Plateau region of Texas. Texas Agr. Exp. Sta. Bull. 1357.

Jung, H.G., R.W. Rice, and L.J. Koong. 1985. Comparison of heifer weight gains and forage quality for continuous and short-duration grazing systems. J. Range Manage. 38:144-148.

Little, T.M., and F.J. Hills. 1978. Agricultural experimentation: Design and analysis. John Wiley and Sons, New York.

Pluhar J.J., R.W. Knight, and R.K. Heitschmidt. 1987. Infiltration rates and sediment production as influenced by grazing systems in the Texas Rolling Plains. J. Range Manage. 40:240-243.

Savory, A., and S.D. Parsons. 1980. The Savory grazing method. Rangelands 2:234-237.

Snedecor, G.W., and W.C. Cochran. 1967. Statistical methods. 6th ed. Iowa St. Univ. Press, Ames.

Tilly, J.M.A., and R.A. Terry. 1963. A two-stage technique for the in vitro digestion of forage crops. J. Brit. Grassland Soc. 18:104-111.

Uresk, D.W., and P.L. Sims. 1975. Influence of grazing on crude protein content of blue grama. J. Range Manage. 28:370-371.

Van Soest, P.J., and R.H. Wine. 1967. Use of detergents in the analyses of fibrous feeds. IV. The determination of plant cell wall constituents. Ass. Off. Anal. Chem. 50:50.

Walker, J.W., and R.K. Heitschmidt. 1986. Effect of various grazing systems on type and density of cattle trails. J. Range Manage. $39: 428-431$ 